\title{
The gender gap in the human capital of the restaurant sector
}

\section{La brecha de género en el capital humano del sector restuaurantero}

\author{
GALVÁN-ISMAEL， María Quetzalcihuatl ${ }^{1} \dagger^{*}$ ， GONZÁLEZ-LAZALDE， Iván ${ }^{1}$, HERNÁNDEZ- \\ CHAVARRÍA, Juana ${ }^{2}$ and RIVAS-BARRAZA, Anapaula ${ }^{1}$
}

${ }^{1}$ Tecnológico Nacional de México/ I. T. Durango

${ }^{2}$ CONACyT-Tecnológico Nacional de México/I.T. Durango

ID 1st Autor: María Quetzalcihuatl, Galván-Ismael / ORC ID: 0000-0003-3117-5121, CVU CONACYT ID: 407045

ID $1^{\text {st }}$ Co-author: Iván, González-Lazalde / ORC ID: 0000-0002-6728-4381, CVU CONACYT ID: 234949

ID $2^{\text {nd }}$ Co-author: Juana, Hernández-Chavarría / ORC ID: 0000-003-0268-6280, CVU CONACYT ID: 271759

ID $3^{\text {rd }}$ Co-author: Anapaula, Rivas-Barraza / ORC ID: 0000-0003-3950-7469, CVU CONACYT ID: 411134

DOI: $10.35429 / J B D S .2021 .20 .7 .21 .30$

Received July 15, 2021; Accepted December 30, 2021

\begin{abstract}
The purpose of this paper is to analyze the gender gap in the performance of activities and capacities in the manager position in micro and small restaurant companies in the city of Victoria, Durango. The Portela Human Capital Index (PHCI) and performance measurement were determined considering the labor competence standards CONOCER EC0422. The construct was validated through the Cronbach's alpha coefficient and the correlation of the performance indicators with those of human capital was sought; hypothesis tests were performed with non-parametric statistics searching for the behavior sample of men vs women. Results show demographic and performance characteristics; statistically they do not show significant differences between genders, although they show that men obtained the manager position at a younger age than women, even if having less experience. The proportion of women who must have a bachelor's degree to be considered for the position, compared to men, is higher. Finally, job performance is higher in workers who have a higher level of human capital, specifically in understanding and managing laws and regulations.
\end{abstract}

Gender gap, Job performance, Human Capital

\section{Resumen}

El propósito del trabajo fue analizar la brecha de género en el desempeño de las actividades y capacidades del puesto de gerente en las empresas micro y pequeñas restauranteras de la ciudad de Victoria de Durango. Se determinaron el Índice de Capital Humano de Portela (ICHP) y medición del desempeño, considerando las normas de competencia laboral CONOCER EC0422. Se validó el constructo a través del coeficiente alfa de Cronbach y se buscó la correlación de los indicadores de desempeño con los de capital humano; se hicieron pruebas de hipótesis con estadística no paramétrica buscando el comportamiento de la muestra de hombres vs mujeres. Los resultados muestran las características demográficas como de desempeño, estadísticamente no muestran diferencias significativas entre género, aunque se puede apreciar en los estadísticos como el hombre accede al puesto de gerente a una edad menor que la mujer, aun teniendo menos experiencia. La proporción de mujeres que deben tener estudios de licenciatura para ser consideradas en el puesto, en el caso del hombre esta proporción es menor. Finalmente, el desempeño laboral es mayor en aquellos trabajadores que tienen un nivel de capital humano más alto, específicamente en la comprensión y la gestión de las leyes y normas.

Brecha de género, Desempeño laboral, Capital Humano

Citation: GALVÁN-ISMAEL, María Quetzalcihuatl, GONZÁLEZ-LAZALDE, Iván, HERNÁNDEZ-CHAVARRÍA, Juana and RIVAS-BARRAZA, Anapaula. The gender gap in the human capital of the restaurant sector. 2021, 7-20: 21-30

\footnotetext{
* Correspondencia del Autor (correo electronico: qgalvan@itdurango.edu.mx)

$\dagger$ Investigador contribuyendo como primer autor.
} 


\section{Introducction}

Eliminating the gender gap is a priority objective for development. Strengthening the participation of women, with full intervention under equal conditions in the decision-making of organizations, should be viewed as a decisive factor for development and progress. The United Nations Development Programme shows that countries with higher Human Development Index have higher levels of Gender Empowerment Index, this could mean that gender equality can be accompanied by a higher level of society development (UN, 2018).

According to data offered by the National Survey of Occupation and Employment 20052009 of the National Institute of Statistics and Geography (Instituto Nacional de Estadística y Geografía - INEGI), the participation of women in the workplace is lower than that of men: 35 out of 100 women contribute to the production of goods and services while 70 out of 100 men have a paid job, which shows that the gap between women from men is still in effect (Instituto de la Mujer Duranguense, 2010). Gender inequality continues to be a problem even today, Opportunities for women in decision-making positions maintain a trend towards the male gender.

Therefore, strengthening the participation of women in managerial positions of companies represents a challenge for society and institutions. Derived from this, a key factor to strengthen equity is the training of intellectual capital of organizations through the development of skills and job competencies in its staff. In the case of the Restaurant Industry, the National System of Competences, of the National Council for Standardization and Certification of Labor Competencies, of the Ministry of Public Education, (CONOCER, 2019) seeks to adapt working conditions for human capital through abilities, skills and attitudes of people, which are acquired at work over time; providing certifications to increase the productivity of organizations and an improved performance of service providers, as well as user satisfaction (Norma Mexicana NMX-R-025-SCFI-2015). Companies must identify what are the skills required by the activities they develop to meet the needs of its customers; therefore, the improvement of individual and collective capacities should be stimulated to improve labor competencies.
In this sense, certifications are an endorsement that allows greater competitiveness in the market, since they are a procedure that guarantees that the product or service offered meets a standard or requirements that support its quality. A certification offers credibility, reliability on the activities, processes, and methodology, it is an added value to the service offered; it allows to distinguish from its competitors, it's an investment of time and resources that benefits the organization by giving recognition to the skills of its human capital, becoming a competitive advantage.

The purpose of this study was to analyze the gender gap that exists in the performance of activities and capacities of men and women who occupy the position of manager in the economic activity of the service sector in the city of Victoria, Durango; specifically, in companies dedicated to the preparation of food and alcoholic and non-alcoholic beverages; for this purpose, the Portela Human Capital Index (PHCI)(Arrazola, María; Hevia, 2003) and the performance measurement established in the labor competence standards CONOCER EC0422 were used.

The central hypothesis is established as to whether the working conditions of performance and knowledge are the same among those who occupy the position of manager between the female and male genders, and to determine from a gender perspective the fundamental differences in the performance of managers, without including salary aspects as this is considered a sensitive variable.

This article consists of five sections; the first section describes the competence standards EC0422 "Management of people in organizations" of the CONOCER Standards used as a basis for the analysis of the manager's competencies and performance. The second section summarizes the importance of the sector studied in the state and in the municipality of Durango. The third section concerns the description of the method used to carry out the study, where the determination of the sample size, the information gathering instruments and the instrument validation are highlighted. The fourth section is related to the results and descriptive analysis of human capital and performance level in the job from a gender perspective. 
In the fifth section, the inferential analysis of performance levels is carried out by applying Pearson's correlation coefficient and a nonparametric statistical hypothesis test to determine the differences between male and female samples of performance levels alongside demographic variables such as: age group, schooling group, and the PHCI, among others. The results are diverse in gender gap and in performance of managers in food and beverage preparation service companies in the city of Victoria, Durango.

\section{Competence Standards EC0422}

The labor competence regulations list the actions that the worker must follow in terms of performance criteria, that is, the expected practices in that specific activity, the fields of application shown through the evidences of fundamental knowledge such as performance methods and principles, and circumstantial knowledge for decision-making adapted to various situations, in addition to the orientation of the evaluation in which the way it will be evaluated is detailed, as well as the evidence obtained for said evaluation (Schwartzman Kaplan, 2000).

The standard of competence for managers is EC0422 "Management of people in organizations", this standard is divided into four elements that make up the competence standards: establish the terms of the individual / collective employment relationship; pay payroll, benefits, and compensation; implement the labor regulations of the organization at the federal and local level; and manage the termination of the employment relationship. In each of these elements, the evaluation criteria are products that the competent person obtains, knowledge that the person must possess to be competent, the responses to emergent situations and attitudes, habits, and values shown.

The level of knowledge achieved must be shown by understanding article 123 of the Political Constitution of the United Mexican States in sections A and B, the content of the Federal Labor Law regarding claims, strike sites and disabilities, that which concerns the related authorities for the fulfillment of individual and collective labor relations (Secretary of Labor and Social Welfare, Federal Attorney's Office for the Defense of Labour, Federal Conciliation and Arbitration Board.
Local Conciliation and Arbitration Board), concept of union relationship, scope and limitations based on the type of collective bargaining agreement, concept, definition and elements of the collective wage and contractual contract and regulations of Federal Employers' Relations (general description of the type of laws, law of the Institute of the National Fund for Workers' Housing [INFONAVIT], the Institute of Social Security and Services for State Workers [ISSSTE], the Pension Saving System [SAR] and the Mexican Institute of Social Security [IMSS]), knowledge of payroll in terms of the concept, elements and process, structure, laws and applicable regulations and knowledge regarding the internal normativity of the internal regulations and collective contract; Likewise, the standard assesses the level of performance in terms of: incident management, payroll calculation process, representation of the organization before the Federal Conciliation and Arbitration Board (JFCA), application of the exit protocol in all cases (death, resignation and dismissal) and in obtaining the various elaborated products, such as:

Safety and hygiene regulations, internal regulations, integrated individual contract, integrated collective contract, integrated special contract, processed payroll, monthly and annual report of the information required for tax and employer obligations, administrative withdrawal form, checklist of exit protocols, settlement, settlement format and exit interview or survey format. For the manager to be competent according to the standard; attitudes, habits and values regarding responsibility, cooperation, order and kindness are also measured. Regarding emergent situations, this refers to extreme circumstances that the manager must face in the labor relationship with his workers, human resource management and representation in the JFCA when physical and verbal aggressions are triggered (CONOCER, 2021).

\section{Importance of the sector in the state and municipality of Durango, Dgo}

The restaurant sector is part of the 72nd classification, corresponding to temporary accommodation and food and beverage preparation services of the Automated Census Information System (SAIC) of the National Institute of Statistics and Geography (INEGI). 
At the national level, as of 2018, 637,124 economic units were registered (UE); In Durango, the registered economic units were 56,236 , which represents $8.8 \%$ of the national total. In relation to 2014 there was an increase of 765 UE in Durango, which means a growth of 6\% (INEGI, 2019).

In the state of Durango, Total Gross Production (TGP) as of 2018 was of 5,008.18 million pesos; In the case of investment, it was 70.6 million pesos. Regarding the employed personnel, 26,886 people were employed in this sector during 2018.

The results of the INEGI, for 2018, show that most of the companies in the restaurant sector installed in Durango where micro (with up to 10 employees), 8, 216 companies join this stratum. Small-sized companies follow with 276 units, and only 14 companies are medium and large with up to 250 employees. At the municipal level, the municipality with the most presence in the restaurant sector is the state capital, Durango, with 25,204 economic units, the city of Lerdo follows with 3,537 companies; Santiago Papasquiaro and Guadalupe Victoria are next, with 1,861 and 1,682 respectively. These five municipalities cover $76.2 \%$ of the economic units of the restaurant sector in the state of Durango.

\section{Description of the methodology}

The considered universal population were 98 micro and small companies in the city of Victoria, Durango which met the characteristic in their functional structure of having at least a manager, a chef, and a cook. This article only shows the results of the analysis carried out in the manager position. To determine the sample size, the formula for finite populations was applied considering a confidence level of $95 \%$ and a sampling error of 0.07 , with which a sample size of 65 companies was obtained.

$n=\frac{k^{2} N p q}{e^{2}(N-1)+k^{2} p q}$

\section{Where:}

$\mathrm{n}=$ is the size of the population sample

$\mathrm{N}=$ is the size of the total population

$\sum=$ population standard deviation

$\mathrm{z}=$ confidence level

$\mathrm{e}=$ sampling error limit

$\mathrm{p}=$ expected proportion

$\mathrm{k}=$ confidence level constant

ISSN: 2444-4960

ECORFAN® All rights reserved
The sampling frame was designed from the data produced by the search carried out in the National Statistical Directory of Economic Units (DENUE, INEGI) selecting companies, probabilistically, for which a list of random numbers was generated using Office Excel v.16 software and choosing 65 numbers according to the list of the sampling frame going to the indicated establishment, in case the company was not found or refused to participate in the study, the next one was considered according to the random selection list created. It's worth mentioning that the information was collected at the end of 2020 and the beginning of 2021, therefore, due to the current pandemic situation, many of the establishments faced closure situations.

For the analysis of the level of competencies achieved by the managers of the companies under study, the Competency Standard CONOCER EC0422 was considered, establishing the manager's perception regarding the performance of the workers he/she directs, his/her employment relationship regarding knowledge of regulations and employment contracts, the management of labor regulations subject to the management of incidents, wages and salaries and Federal Conciliation and Arbitration Board, employment relationship in terms of protocols for dismissals, departures, layoffs, death, liquidation and exit surveys, supervision of work, areas and clients, knowledge of labor laws (Constitution, Federal Labor Law, collective relations, unions, contracts and employer regulations, payroll management and tax laws and regulation management, Internal Regulation of Work, fires, training, working conditions and safety and hygiene), for which a questionnaire that consisted of four sections was designed: in the first one, demographic data such as gender, age and number of workers in the company and information for the calculation of the PHCI (years of schooling and years of experience) were collected; subsequent sections were designed in response of a five-entry Likert scale (always, almost always, sometimes, almost never and never); the second section is related to the activities carried out in the workplace; the third section is related to the knowledge maintained according to their perception; and the fourth section is related to their attitude, habits and values. 
The performance analysis variables were classified into eight indicators: 'perception of worker performance by manager' where the perception of the manager in relation to the range of delivery and performance of the workers within the company they run is analyzed; 'knowledge of labor relations' which includes knowledge of the safety and hygiene regulations for the variables, of the internal regulations drawn up, of the integrated individual contract, of the integrated collective contract and the integrated special contract; "knowledge of labor regulation management' which contains the incident management variables, salary and compensation management, and representation of the company before the JFCA; 'management of the employment relationship' which integrates the application of exit protocols in all cases and elaborates the discharge forms, checklists, delivery of elaborated settlement forms, and carries out the exit interviews or survey formats; 'management of work supervision' in correspondence to the variables regarding preservice meetings with the personnel under their charge, to monitor the conditions of the room where food and beverage service are provided, to report needs for the conditioning of facilities, to verify the operation equipment and processes, supervise the activities assigned to personnel, verify the garbage area, verify the assembly of the beverage service area, serve diner during their stay, supervise prepared food and beverages, monitor diner attention, verify food and beverage service orders, verify consumer bills;

'knowledge of labor laws and regulations' corresponding to the variable knowledge of article 123 of the Political Constitution of the United Mexican States, of the content of the Federal Labor Law in terms of lawsuits, strike calls and disabilities, of the authorities related to the fulfillment of individual and collective labor relations (STPS, PFDT, JFCA y JLCA), of the concept of union relationship, scope and limitations based on the type of collective contract agreement, of the concept and elements of the collective wage and contractual agreement and the regulations of federal employer relations; 'payroll management and tax laws ' subject to knowledge of concepts and elements of the types of payroll, the payroll process interfaces, concept and structure of the payroll audit process.
Of the Federal Tax Regulations of the Federal Tax Code, of the Federal and Local Tax Regulations regarding payroll tax and the concepts and application of internal regulations; 'Work standards management', under the variables and knowledge of the Federal Labor Law (incentives, commissions, penalties, compensation and retirements), of the elements to attend a general inspection of working conditions, training, safety and hygiene by the STPS and internal regulations. It was determined through the mean of the indicators that the overall performance level of the Standard CONOCER EC0422.

The validation and consistency of the instrument with which the information was collected on those variables contained in some of the indicators was carried through Cronbach's alpha coefficient. Considering the group of variables according to their indicator, Table 1 shows the results with an average of 0.857 , which is considered by various authors as a good level of reliability.

\begin{tabular}{|c|c|}
\hline Indicator & $\begin{array}{l}\text { Cronbach's alpha } \\
\text { coefficient }\end{array}$ \\
\hline Knowledge of labor relations & 0.796 \\
\hline $\begin{array}{l}\text { Management of } \\
\text { employment relationship }\end{array}$ & 0.839 \\
\hline $\begin{array}{ll}\text { Work } & \text { supervision } \\
\text { management } & \\
\end{array}$ & 0.826 \\
\hline $\begin{array}{l}\text { Knowledge of labor laws and } \\
\text { regulations }\end{array}$ & 0.870 \\
\hline $\begin{array}{l}\text { Payroll management and tax } \\
\text { laws }\end{array}$ & 0.921 \\
\hline $\begin{array}{l}\text { Management of } \\
\text { standards }\end{array}$ & 0.893 \\
\hline
\end{tabular}

Table 1 Cronbach's alpha coefficient of each indicator Source: Own Elaboration

The sample was grouped into female and male managers to determine the statistical differences presented in relation to some demographic variables, PHCI and performance indicators. The Pearson correlation coefficient was determined with the performance indicators, the software used was SPSS V25. for nonparametric statistics in hypothesis tests applying the Kruskal Wallis test and the Minitab V.19 software for the Mann Whitney tests. 


\section{Results of gender descriptive analysis, human capital index and level of performance}

Managers were studied from a gender perspective to determine the gender gap in performance within the managerial level in this economic activity, finding that the age is very similar between the two genders with an average of 37 years for women and 33 years for men, with a standard deviation of 11 years for women and 10 for men. Regarding years of schooling, it was found that both men and women have truncated undergraduate level studies on average with a standard deviation of three years. In relation to the years of experience in the development of this activity, it's lower for men compared to women; the average years of experience for men is that of 7.37 and for women is 8.07. Table 2 shows the mean and standard deviation of the manager's age, years of study and years of experience for men and women.

\begin{tabular}{|c|c|c|c|c|c|c|}
\hline & \multicolumn{2}{c}{$\begin{array}{c}\text { Manager's } \\
\text { age }\end{array}$} & \multicolumn{2}{c}{$\begin{array}{c}\text { Years of } \\
\text { study }\end{array}$} & \multicolumn{2}{c|}{$\begin{array}{c}\text { Years of } \\
\text { experience }\end{array}$} \\
\hline & $\overline{\mathrm{x}}$ & $\mathrm{s}$ & $\overline{\mathrm{x}}$ & $\mathrm{s}$ & $\overline{\mathrm{x}}$ & $\mathrm{s}$ \\
\hline $\mathrm{W}^{*}$ & 37.37 & 11.73 & 14.50 & 3.13 & 8.07 & 8.53 \\
\hline $\mathrm{M}^{* *}$ & 32.89 & 10.04 & 14.86 & 3.14 & 7.37 & 7.49 \\
\hline
\end{tabular}

Table 2 Comparative descriptive statistics women and men age of the manager, years of study and years of experience

Source: Own Elaboration

Regarding the number of employees that men and women manage, it's also very similar with a small difference, the average number of employees for women is 14.73 and for men is 13.6, the PHCI (formula 2 in annexes) is similar for both men (14.37) and women (14.32). Table 3 shows the mean and standard deviation of the number of employees and the PHCI.

\begin{tabular}{|c|c|c|c|c|}
\hline & \multicolumn{2}{|c|}{ Number of employees } & \multicolumn{2}{|c|}{ PHCI } \\
\hline & $\overline{\mathrm{x}}$ & $\mathrm{s}$ & $\overline{\mathrm{x}}$ & $\mathrm{s}$ \\
\hline $\mathrm{W}^{*}$ & 14.73 & 11.25 & 14.32 & 3.64 \\
\hline $\mathrm{M}^{* *}$ & 13.6 & 8.25 & 14.37 & 3.75 \\
\hline
\end{tabular}

Table 3 Comparative descriptive statistics for men and women number of employees and PHCI

Source: Own Elaboration

Table 4 shows the level of education by gender, where it can be observed that the proportion of managers with a truncated high school or lower level is higher in women.
It also highlights that more than twice the percentage of men occupy the position with truncated undergraduate level studies. Regarding managers with a bachelor's degree, women occupy the position 1.5 times higher. The total of managers of both genders who have postgraduate studies only reaches 7.7 percent. It's also observed that for $63 \%$ of men, truncated undergraduate studies or lower was enough to hold position of manager, while these same schooling characteristics are only shown by $50 \%$ of women in the same position. In other words, for a woman to be able to have the position of manager, she requires a bachelor's degree or a postgraduate, with only $37 \%$ of men completing this level of studies.

\begin{tabular}{|l|l|l|l|l|l|l|}
\hline \multicolumn{2}{|c|}{ Women } & \multicolumn{3}{c|}{ Men } & \multicolumn{3}{c|}{ Total } \\
\hline $\begin{array}{l}\text { Level of } \\
\text { education }\end{array}$ & $\mathrm{F}^{*}$ & $\%$ & $\mathrm{~F}^{*}$ & $\%$ & $\mathrm{~F}^{*}$ & $\%$ \\
\hline $\begin{array}{l}\text { Truncated } \\
\text { secondary }\end{array}$ & & & 1 & 2.9 & 1 & 1.5 \\
\hline Secondary & 4 & 13.3 & & & 4 & 6.2 \\
\hline $\begin{array}{l}\text { Truncated } \\
\text { baccalaureate }\end{array}$ & 1 & 3.3 & 2 & 5.7 & 3 & 4.6 \\
\hline Baccalaureate & 5 & 16.7 & 6 & 17.1 & 11 & 16.9 \\
\hline $\begin{array}{l}\text { Truncated } \\
\text { Bachelor's } \\
\text { degree }\end{array}$ & 5 & 16.7 & 13 & 37.1 & 18 & 27.7 \\
\hline $\begin{array}{l}\text { Bachelor's } \\
\text { degree }\end{array}$ & 13 & 43.3 & 10 & 28.6 & 23 & 35.4 \\
\hline Postgraduate & 2 & 6.7 & 3 & 8.6 & 5 & 7.7 \\
\hline
\end{tabular}

* Frequency

Table 4 Level of education for the manager position Source: Own Elaboration

Results of the inferential analysis of performance levels and in relation to demographic variables and PHCI

To define the level of relationship between the variables analyzed in the manager's performance level, the Pearson's correlation coefficient statistical test was applied using the classification established by Hernández Sampieri (2014): very weak positive correlation when the parameter of $0.10>0.25$ is found, weak at $0.25>0.50$, medium at $0.50>0.75$, considerable at $0.75>0.90$, very strong at 0.90 $>1.00$ and perfect at 1.00 . The positive correlation shows a directly proportional relationship. The results show a very weak positive correlation for the case of 'perception of worker performance' by manager in relation to 'employment relationship management' with a relationship of $24.5 \%$. 
A weak positive correlation was shown in the same indicator in relation to "knowledge of labor laws and regulations', 'payroll management and tax laws' and 'management of work standards' with $37.9 \%, 32.0 \%$ and $30.4 \%$ respectively. In contrast, 'knowledge of labor relations' presents a mean positive correlation with 'knowledge of laws and regulations' at a $56.1 \%$ and with 'management of work standards' of 56.9\%. The relationship shown between 'knowledge of labor laws and regulations' with 'payroll management and tax laws' and 'management of work standards' with a considerable correlation coefficient of 0.831 and 0.795 respectively, also stands out. 'Payroll management and tax laws' maintains a considerable positive relationship with 'work standards management' at $88.3 \%$. Table 5 contained in the annexes shows the indicators the relationship with respect to the correlation coefficient.

Likewise, the correlation coefficient was used to determine the relationship of the manager's PHCI level with the years of experience and with the years of study, finding that the correlation for both the years of experience and the years of schooling shows an average positive relationship of $51.6 \%$ and $71.7 \%$, respectively.

The correlation of the performance indicators in relation to the PHCI was also calculated finding that 'knowledge of labor relations', 'knowledge of labor laws and regulations' and 'management of work standards' maintain a weak positive correlation of $0.371,0.265$ and 0.246 , respectively. By determining that years of schooling maintain a higher coefficient relationship with the PHCI the relationship of years of schooling with each of the indicators related to the manager's performance was calculated finding that 'knowledge of management of the labor norm', 'management of the employment relationship' maintain a weak positive relationship with a coefficient of 0.316 and 0.274 respectively with the manager's years of schooling. The relationship between the manager's years of schooling and the manager's level of performance was also determined according to the EC0422 standard, finding a similar result (weak positive correlation) of 0.256 .
For inferential analysis between performance levels and demographic and PHCI variables, hypothesis tests were applied using non-parametric statistics with the Kruskal Wallis test to determine the gender gap in the manager position, finding that within the distribution of the eight indicators analyzed relative to the performance, no statistically significant differences were found between men and women.

The demographic characteristics of the managers in the restaurants of the city of Victoria, Durango was also determined by applying the hypothesis test under the same test, finding that the number of workers they manage, the age of the manager, the manager's years of schooling, their years of experience and the PHCI do not show statistically significant differences between the capacities and performances of women who occupy the position of managers with respect to their male colleagues. As can be seen in graph 1, the box plots show the dispersion by gender for different demographic variables.

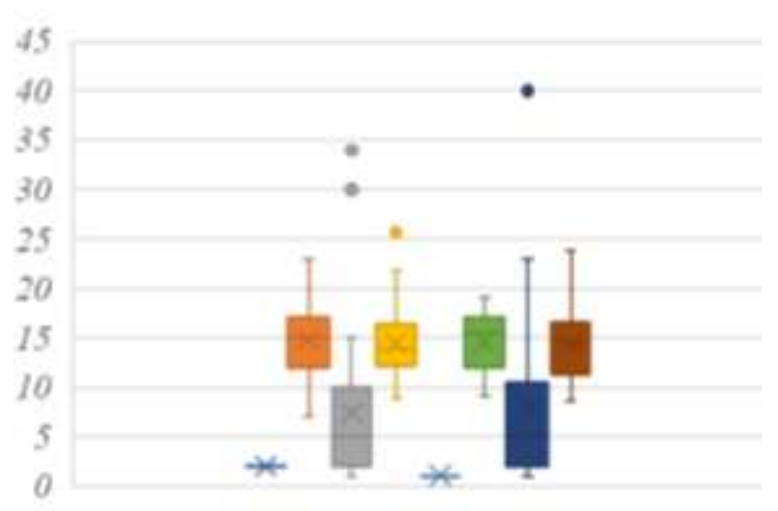

Men Gender

Years of formal study

Years of experience

PHCI

Women Gender

Years of formal study

Years of experience

Graph 1 Gender gap in years of schooling, years of experience and PHCI of managers

Source: Own Elaboration 
The indicators related to the level of performance of the managers were analyzed in relation to the PHCI group, manager's group of years of schooling manager's age group, and company size categories applying the Kruskal Wallis hypothesis test. If the alternative hypothesis was accepted, the Mann Whitney test was applied with a confidence level of $95 \%$ using the test of one population different from another. A population is > or < to another to determine group differences.

In the case of the PHCI, its results were grouped into four categories: level 1 Low (PHCI $<10)$, level 2 Medium $(10>$ PHCI < 15), level 3 Medium High $(15>$ PHCI $<20)$ and level 4 High (PHCI > 20). When applying the hypothesis test, it was determined that the distribution of knowledge of labor relations is not the same between the PHCI group categories with a significance level of 0.021 . The Mann Whitney analysis was applied to determine differences comparing two groups, finding that level 1 group is less than level 3 group, level 1 group is lower than level 4 group, and level 2 group is lower than the level 4 group with a significance level of $0.032,0.005$ and 0.007 respectively, with which it can be observed that the PHCI of the level 4 group in the knowledge of the regulations concerning labor relations is higher than in other groups.

For the years of schooling, the results were categorized into five groups starting from group 3 to 7 ; truncated secondary studies (less than 9 years), finished secondary (9 years of study) and truncated baccalaureate (10 and 11 years) were joined in group 3 because the elements of truncated and finished secondary were few, which made separate analysis impossible; group 4 finished baccalaureate (12 years); group 5 truncated undergraduate level (13 to 15 years); group 6 completed bachelor's degree (16 to 17 years); and group 7 postgraduate studies with more than 18 years of schooling. When applying the hypothesis test regarding the distribution of the performance level indicators, it was found that for the case of 'payroll management and tax laws' and 'management of work standards' different results are shown with a significance level of 0.024 and 0.013 respectively, therefore, the Mann Whitney test is applied, resulting in differences for 'payroll management and tax laws' in group 4 as it was lower than group 5 and group 6 with a significance level of 0.011 and 0.005 respectively.
The above indicates that 'payroll management' and 'knowledge of tax laws' in the completed baccalaureate group (group 4) had lower results than those for truncated bachelor's degree (group 5) and completed (group 6). Referring to 'work standards management' the null hypothesis was rejected with a significance level of 0.013, when applying the test to determine differences by groups, group 4 was found to be lower than group 6 and group 7 with a significance level of 0.012 and 0.008 , that means that 'work standards management' of the completed baccalaureate group showed a lower response scale than truncated bachelor's degree and postgraduate.

Performance indicators were averaged by applying the Mann Whitney test to all groups, finding that group 4 statistically showed a lower level of performance than group 6 with 0.072 . It should not be forgotten that the questionnaires consider the perception of the managers regarding their own competencies and carried out (performances) activities with answers of always, almost always, sometimes, almost never and never, so it can be deduced that since coursing baccalaureate, managers become aware of their level of knowledge and activities established in the Standard CONOCER EC0422 in the aforementioned indicators.

The age of the manager was also evaluated with respect to the distribution of each of the performance indicators resulting in "knowledge of management of the labor norm ' to be different with a significance level of 0.010 , so the following relative test was applied to the age groups, group 1 contains managers $<30$ years, group 2 from ages 31 to 40 , group 3 from ages 41 to 50 and group 4 from ages 51 to 60 or more years of age. The results showed that group 1 is lower than group 2 and higher than group 3 with a significance level of 0.012 and 0.020 respectively, group 2 is higher than group 3 with a significance level of 0.001 and group 3 lower than group 4 with a significance level of 0.011 .

The size of the company was another group considered in the hypothesis tests in relation to performance indicators, as already mentioned, the study observed micro and small companies, resulting in the acceptance of the alternative hypothesis for the 'management of labor regulations and management of payroll and tax laws' with a significance level of 0.038 and 0.036 respectively. 
When applying the test of differences by company size, it was shown that in these two indicators micro companies have lower performance results than small companies with a significance level of 0.032 and 0.008 , respectively, Therefore, it can be assumed that the managers of micro companies recognize the lack of knowledge of management of labor regulations and management of payroll and tax laws.

\section{Annexes}

\begin{tabular}{|c|c|c|c|}
\hline $\begin{array}{c}\text { Correlation } \\
\text { classificatio } \\
\text { n }\end{array}$ & Indicator & Indicator & $\begin{array}{c}\text { Correlatio } \\
\text { n } \\
\text { coefficient }\end{array}$ \\
\hline $\begin{array}{l}\text { Very weak } \\
\text { positive } \\
\text { correlation } \\
0.10>0.25\end{array}$ & \multirow{4}{*}{$\begin{array}{l}\text { Perception } \\
\text { of worker } \\
\text { performance } \\
\text { by manager }\end{array}$} & $\begin{array}{l}\text { Labor } \\
\text { relationship } \\
\text { management }\end{array}$ & 0.245 \\
\hline \multirow{3}{*}{$\begin{array}{l}\text { Weak } \\
\text { positive } \\
\text { correlation } \\
0.25>0.50\end{array}$} & & $\begin{array}{l}\text { Knowledge } \\
\text { of labor laws } \\
\text { and } \\
\text { regulations }\end{array}$ & 0.379 \\
\hline & & $\begin{array}{l}\text { Payroll } \\
\text { management } \\
\text { and tax laws }\end{array}$ & 0.320 \\
\hline & & $\begin{array}{l}\text { Managemen } \\
\mathrm{t} \text { of work } \\
\text { standards }\end{array}$ & 0.304 \\
\hline \multirow{3}{*}{$\begin{array}{l}\text { Weak } \\
\text { positive } \\
\text { correlation } \\
0.25>0.50\end{array}$} & \multirow{5}{*}{$\begin{array}{l}\text { Knowledge } \\
\text { of labor } \\
\text { relations }\end{array}$} & $\begin{array}{l}\text { Knowledge } \\
\text { of labor } \\
\text { regulation } \\
\text { management }\end{array}$ & 0.399 \\
\hline & & $\begin{array}{l}\text { Work } \\
\text { supervision } \\
\text { management }\end{array}$ & 0.373 \\
\hline & & $\begin{array}{l}\text { Payroll } \\
\text { management } \\
\text { and tax laws }\end{array}$ & 0.445 \\
\hline \multirow{2}{*}{$\begin{array}{l}\text { Mean } \\
\text { positive } \\
\text { correlation } \\
0.50>0.75\end{array}$} & & $\begin{array}{l}\text { Knowledge } \\
\text { of labor laws } \\
\text { and } \\
\text { regulations }\end{array}$ & 0.561 \\
\hline & & $\begin{array}{l}\text { Managemen } \\
\mathrm{t} \text { of work } \\
\text { standards }\end{array}$ & 0.569 \\
\hline \multirow{4}{*}{$\begin{array}{l}\text { Weak } \\
\text { positive } \\
\text { correlation } \\
0.25>0.50\end{array}$} & \multirow{5}{*}{$\begin{array}{l}\text { Knowledge } \\
\text { of labor } \\
\text { regulation } \\
\text { management }\end{array}$} & $\begin{array}{l}\text { Managemen } \\
\mathrm{t} \text { of the } \\
\text { employment } \\
\text { relationship }\end{array}$ & 0.396 \\
\hline & & $\begin{array}{l}\text { Work } \\
\text { supervision } \\
\text { management }\end{array}$ & 0.461 \\
\hline & & $\begin{array}{l}\text { Knowledge } \\
\text { of labor } \\
\text { regulation } \\
\text { management }\end{array}$ & 0.461 \\
\hline & & $\begin{array}{l}\text { Managemen } \\
\mathrm{t} \text { of work } \\
\text { standards }\end{array}$ & 0.457 \\
\hline $\begin{array}{l}\text { Mean } \\
\text { positive } \\
\text { correlation } \\
0.50>0.75\end{array}$ & & $\begin{array}{l}\text { Knowledge } \\
\text { of labor laws } \\
\text { and } \\
\text { regulations }\end{array}$ & 0.520 \\
\hline $\begin{array}{l}\text { Weak } \\
\text { positive }\end{array}$ & $\begin{array}{l}\text { Managemen } \\
t \text { of the }\end{array}$ & $\begin{array}{l}\text { Work } \\
\text { supervision } \\
\text { management }\end{array}$ & 0.498 \\
\hline
\end{tabular}

\begin{tabular}{|c|c|c|c|}
\hline \multirow[t]{3}{*}{$\begin{array}{l}\text { correlation } \\
0.25>0.50\end{array}$} & \multirow[t]{3}{*}{$\begin{array}{l}\text { employment } \\
\text { relationship }\end{array}$} & $\begin{array}{l}\text { Knowledge } \\
\text { of labor laws } \\
\text { and } \\
\text { regulations }\end{array}$ & 0.457 \\
\hline & & $\begin{array}{l}\text { Payroll } \\
\text { management } \\
\text { and tax laws }\end{array}$ & 0.457 \\
\hline & & $\begin{array}{l}\text { Managemen } \\
\mathrm{t} \text { of work } \\
\text { standards }\end{array}$ & 0.498 \\
\hline \multirow{3}{*}{$\begin{array}{l}\text { Weak } \\
\text { positive } \\
\text { correlation } \\
0.25>0.50\end{array}$} & \multirow{3}{*}{$\begin{array}{l}\text { Work } \\
\text { supervision } \\
\text { management }\end{array}$} & $\begin{array}{l}\text { Knowledge } \\
\text { of labor laws } \\
\text { and } \\
\text { regulations }\end{array}$ & 0.310 \\
\hline & & $\begin{array}{l}\text { Payroll } \\
\text { management } \\
\text { and tax laws }\end{array}$ & 0.368 \\
\hline & & $\begin{array}{l}\text { Managemen } \\
\mathrm{t} \text { of work } \\
\text { standards }\end{array}$ & 0.394 \\
\hline \multirow{2}{*}{$\begin{array}{l}\text { Considerable } \\
\text { positive } \\
\text { correlation } \\
0.75>0.90\end{array}$} & \multirow{2}{*}{$\begin{array}{l}\text { Knowledge } \\
\text { of labor laws } \\
\text { and } \\
\text { regulations }\end{array}$} & $\begin{array}{l}\text { Payroll } \\
\text { management } \\
\text { and tax laws }\end{array}$ & 0.831 \\
\hline & & $\begin{array}{ll}\text { Gestión } & \text { de } \\
\text { normas } & \text { de } \\
\text { trabajo } & \\
\end{array}$ & 0.795 \\
\hline $\begin{array}{l}\text { Considerable } \\
\text { positive } \\
\text { correlation } \\
0.75>0.90 \\
\end{array}$ & $\begin{array}{l}\text { Payroll } \\
\text { management } \\
\text { and tax laws }\end{array}$ & $\begin{array}{l}\text { Managemen } \\
\mathrm{t} \text { of work } \\
\text { standards }\end{array}$ & 0.883 \\
\hline
\end{tabular}

Table 5 Pearson correlation performance indicators Source: Own Elaboration

The calculation of the PHCI is carried out through equation (2) which makes it possible to equate the experience acquired over the years with the level of studies that the people subject to analysis have (Portela, 2001).

$$
\begin{aligned}
& C H P i=\mathrm{MEDU} X(0.5+ \\
& \left.\frac{e^{\frac{(E D U i-M E D U)}{(D T E D U)}}}{1+e^{\frac{(E D U i-M E D U)}{(D T E D U)}}}\right) \mathrm{X}(0.5+ \\
& \left.\frac{e^{\frac{(E X P E i-M E X P E)}{(D T E X P E)}}}{1+e^{(E X P E i-M E X P E) /(D T E X P E)}}\right)
\end{aligned}
$$

Where:

$M E D U=$ Average educational level of the agricultural population

$E D U i=$ Educational level of the i-th individual $D T E D U=$ Standard deviation of said educational level

EXPEi $=$ Work experience of the $\mathrm{i}$-th individual $M E X P E=$ Average experience of the agricultural population

DTEXPE $=$ Standard deviation of said work experience 


\section{Acknowledgment}

The research was financed by the National Technological Institute of Mexico (Tecnológico Nacional de México - TecNM).

\section{Conclusions}

At present, there is still a gender gap in most managerial-level positions, therein lies the importance of this study to understand this phenomenon and to create policies to improve this situation. Research shows that both demographic and performance characteristics statistically do not show significant differences between the restaurants lead by women and men, and although statistically they are not different, it can be seen that on average, men access the position of manager at an age five years younger than women, even when having less work experience.

This means that, in order to reach the management level, women not only need to have the same level of human capital and performance as a man, in addition, they need to have more time of professional work to be recognized for the position. This shortens the working lives of women in managerial positions and therefore their access to better salaries and benefits than their male counterparts. It is also concluded that to occupy the position of manager, truncated undergraduate level studies or lower are enough for men, while for a woman in the manager position a completed bachelor's degree or postgraduate studies is needed. It's clear that job performance is higher in workers who have a higher level of human capital, specifically in understanding and managing laws and regulations that frame a better performance of organizations. The study shows that larger companies allow them to have a higher level of human capital.

\section{References}

Arrazola, María; Hevia, J. (2003). Measurement of human capital and analysis of its performance. Instituto de Estudios Fiscales, 3-36.

CONOCER. (2021).National Council for Standardization and Certification of labor competencies. Retrieved from https://conocer.gob.mx/
Hernández Sampieri, R., Fernández Collado, C., y Baptista Lucio, P. (2014). Metodología de la Investigación ( $6^{\mathrm{a}}$ ed.). México, México: McGrawHill

Duranguense Women's Institute (2010). Diagnosis of gender inequality gaps in the social sector of the state of Durango. http://cedoc.inmujeres.gob.mx/ftpg/Durango/dg ometa3.pdf

National Institute of Statistic and Geography (INEGI) (2021), Economic censuses: Automated Census Information System (SAIC). https://www.inegi.org.mx/app/saic/

United Nations (2018), The 2030 Agenda for Sustainable Development. https://www.cepal.org/es/publicaciones/40155la-agenda-2030-objetivos-desarrollo-sostenibleoportunidad-america-latina-caribe

Mexican Standard NMX-R-025-SCFI-2015, Labor Equality and Non-Discrimination. https://www.gob.mx/inmujeres/acciones-yprogramas/norma-mexicana-nmx-r-025-scfi2015-en-igualdad-laboral-y-no-discriminacion

National Statistical Directory of Economic Units (2021) (DENUE, INEGI) https://www.inegi.org.mx/app/mapa/denue/defa ult.aspx

Portela, M. (2001). Measuring skill: a multidimensional index. Econonomics Letters, 2732.

Schwartzman Kaplan, Rebeca (2000). Training Based on Labor Competency Standards. An alternative for the new millennium in terms of training. Revista del Centro de Investigación. Universidad La Salle, 4 (14), 87-93. [Consultation Date November 15, 2021]. ISSN: 1405-6690. Available at: https://www.redalyc.org/articulo.oa?id=342014 11 